\title{
The 2013 clinical course descriptors for multiple sclerosis
}

\author{
A clarification
}

Fred D. Lublin, MD, Timothy Coetzee, PhD, Jeffrey A. Cohen, MD, Ruth A. Marrie, MD, PhD, and Alan J. Thompson, MD, on behalf of the International Advisory Committee on Clinical Trials in MS

Neurology ${ }^{\circledR}$ 2020;94:1088-1092. doi:10.1212/WNL.0000000000009636

\section{Correspondence}

Dr. Lublin

fred.lublin@mssm.edu

\section{Abstract}

The clinical courses of multiple sclerosis were defined in 1996 and refined in 2013 to provide a time-based assessment of the current status of the individual. These definitions have been successfully used by clinicians, clinical trialists, and regulatory authorities. Recent regulatory decisions produced variations and discrepancies in the use of the clinical course descriptions. We provide here a clarification of the concepts underlying these descriptions and restate the principles used in their development. Importantly, we highlight the critical importance of time framing the disease course modifiers activity and progression and clarify the difference between the terms worsening and progressing.

\section{Introduction}

In 1996, the International Advisory Committee on Clinical Trials in MS (a body currently sponsored by the European Committee for Treatment and Research in MS and the US National Multiple Sclerosis Society) published an article defining the clinical course of multiple sclerosis (MS). ${ }^{1}$ These definitions were subsequently updated in $2013 .{ }^{2}$ The purpose of these consensus descriptions was to standardize the terminology used to characterize the different clinical courses of MS and (in the 2013 revision) add descriptors for the current state of the patient.

Accurate, standardized clinical course descriptors are important for several reasons. First, they facilitate communication between clinicians and persons with MS. Second, they are necessary to support studies describing the natural history of MS and facilitate accurate identification of prognostic indicators by clinical course. Third, they reduce heterogeneity in the populations recruited for clinical trials and assist in the application of trial results to appropriate patient populations in clinical practice.

The current classifications of MS have been generally accepted by clinicians, researchers, sponsors, and regulators. However, recent approvals for several disease-modifying therapies, including ocrelizumab, siponimod, and cladribine, introduced variations and some discrepancies in the use of the clinical course descriptors in the associated regulatory communications. ${ }^{3-8}$ Variation in the application of the clinical course descriptors has the potential to create some confusion in clinical practice, the conduct of future clinical trials, and decisions by health authorities, insurers, and related entities concerning patient access

From the Department of Neurology (F.D.L.), Corinne Goldsmith Dickinson Center for Multiple Sclerosis, Icahn School of Medicine at Mount Sinai, New York, NY; National Multiple Sclerosis Society (T.C.), New York, NY; Department of Neurology (J.A.C.), Mellen Center for Multiple Sclerosis Treatment and Research, Neurological Institute, Cleveland Clinic, OH; Departments of Internal Medicine (Neurology) and Community Health Sciences (R.A.M.), Rady Faculty of Health Sciences, Max Rady College of Medicine, University of Manitoba, Winnipeg, Canada; and Faculty of Brain Sciences (A.J.T.), University College, London, United Kingdom.

Go to Neurology.org/N for full disclosures. Funding information and disclosures deemed relevant by the authors, if any, are provided at the end of the article. 


\section{Glossary}

MS = multiple sclerosis; PPMS = primary progressive multiple sclerosis; SPMS = secondary progressive multiple sclerosis.

to approved treatments. This situation has prompted the committee to clarify the concepts underlying these descriptions and to restate the principles used in their development.

\section{Multiple sclerosis phenotypes}

Since 2013, the phenotypes that have been used to characterize MS are clinically isolated syndrome (monophasic clinical episode typical of CNS demyelination in a patient not known to have MS), relapsing-remitting MS, primary progressive MS (PPMS), and secondary progressive MS (SPMS), and they are referenced in the recently published MS diagnostic criteria. ${ }^{9}$ The modifiers describing the current disease state are (1) assessments of activity-evidenced either by clinical relapses or imaging (gadolinium-enhancing lesions or new or unequivocally enlarging T2 lesions) — and (2) an assessment of progression-clinical evidence of disability worsening, independent of relapses, over a given period of time in patients who are in a progressive phase of the disease (i.e., PPMS or SPMS). ${ }^{2}$

A critical aspect of the 2013 addition of modifiers for activity and progression was that these terms must be framed in time. ${ }^{2}$ Although a specific time frame was not initially specified, we recommended and reaffirm that at a minimum, disease activity and progression should be evaluated annually. When used in this manner, the modifiers represent a current assessment of the disease and can enable monitoring of changes over time.

As stated in the committee's previous articles, these recommended characterizations were based on the clinician's determination of the patient's clinical course. ${ }^{1,2}$ Although these characterizations are informed by our understanding of the pathobiology underlying the clinical courses, this pathobiology is incompletely understood. There is a common view that the underlying pathology of MS involves both inflammation and neurodegeneration. However, the relationship between the clinical evolution of the disease and these mechanisms is complex and requires further characterization. Although MRI remains an incomplete indicator of disease course, it has increasing utility as a measure of activity, as discussed below.

\section{Challenges}

The phenotype characterizations are widely used, but we have observed increasing inconsistency in how they are applied, particularly by regulatory authorities. Specific areas of concern include the use of the terms activity, progression, and worsening.

Regulators in Europe and the United States have used different definitions of activity in recent marketing authorizations for ocrelizumab, siponimod, and cladribine. Whereas European regulators have defined activity as evidenced by relapses or imaging features of inflammatory activity, US regulators limited the definition of activity to clinical relapses; MRI criteria for activity were not mentioned. These definitions are further complicated by the absence of a time frame in the product labels, which have included the terms active SPMS or SPMS with active disease in the United States and Europe. ${ }^{5-7}$ Without a time frame, these terms have little meaning, as all patients with SPMS (which by definition follows a relapsing-remitting phase) experienced active disease at some point. Inclusion of a time frame is critical for effective clinical decision making. A better approach would have been for the US labels for siponimod and cladribine (and the subsequent labeling updates of other approved DMTs) to have used the full definition of activity (i.e., either clinical or MRI activity) and include a specified time period for designating activity in those who are considered active SPMS, as discussed above. This more specific characterization would be understandable based on the concepts we had proposed and could be applied readily by clinicians, health systems, and related entities. The divergence between European and US regulators in use of the clinical course descriptors is problematic as it introduces potential confusion for drug developers, researchers publishing results, clinicians, and persons with MS. ${ }^{8}$ Although a broader labeled indication may provide prescribers greater latitude in determining the indications for an agent, there is a risk that in the absence of a standardized definition, payors, health authorities, and related bodies might use this as an opportunity to restrict access to a needed medication.

For purposes of clarity, we recommend that the more general term worsening be used to describe any increase in impairment/disability irrespective of whether it has resulted from residual deficits following a relapse or increasing disability during the progressive phase of the illness. We recommend reserving the term progressing or disease progression to describe those in a progressive phase of MS (PPMS or SPMS) who are accruing disability, independent of any relapse activity.

\section{Conclusion}

In summary, the committee urges clinicians, investigators, and regulators to consistently and fully use the 2013 phenotype 
Table Definitions and time frames referenced in this article

\begin{tabular}{|c|c|c|}
\hline Term & Definition & Recommended time frame for evaluation \\
\hline \multirow[t]{3}{*}{ Active disease } & $\begin{array}{l}\text { Clinical: relapses, acute or subacute episodes of new or } \\
\text { increasing neurologic dysfunction, followed by full or partial } \\
\text { recovery, in the absence of fever or infection }\end{array}$ & $\begin{array}{l}\text { Annually (but can be another time frame, as } \\
\text { long as it is specified) }\end{array}$ \\
\hline & and/or & \\
\hline & $\begin{array}{l}\text { Imaging: gadolinium-enhancing lesions or new or } \\
\text { unequivocally enlarging } T 2 \text { lesions }\end{array}$ & $\begin{array}{l}\text { Annually (but can be another time frame, } \\
\text { as long as it is specified) }\end{array}$ \\
\hline $\begin{array}{l}\text { Progressing disease } \\
\text { or disease } \\
\text { progression }\end{array}$ & $\begin{array}{l}\text { Accrual of disability, independent of any relapse activity, } \\
\text { during the progressive phase of MS (PPMS or SPMS) }\end{array}$ & $\begin{array}{l}\text { Annually by clinical assessment (but can be } \\
\text { another time frame, as long as it is specified) }\end{array}$ \\
\hline Worsening disease & $\begin{array}{l}\text { Any increase in impairment/disability irrespective of whether it has } \\
\text { resulted from residual deficits following a relapse or (increasing) } \\
\text { progressive disability during the progressive phase of the illness }\end{array}$ & Not required \\
\hline
\end{tabular}

Abbreviations: PPMS = primary progressive multiple sclerosis; SPMS = secondary progressive multiple sclerosis.

characterizations by (1) using the full definition of activity, that is, the occurrence of a relapse or new activity on an MRI scan (a gadolinium-enhancing lesion or a new/unequivocally enlarging T2 lesion $)^{2}$; (2) framing activity and progression in time; and (3) using the terms worsening and progressing or disease progression more precisely when describing MS course. The recommended terms and relevant time frames are defined in the table.

We recognize that terminology and classification of the MS disease course are dynamic and will require redefining and clarifications as new data and measurement approaches become available, with the goal of developing more biologically based disease course characterizations that provide clarity and avoid unintended consequences. To this end, the committee is planning for their next review of this topic for 2020 to revisit the clinical courses with a particular focus on progression and the contributors to progression.

\section{Study funding}

This work and the International Advisory Committee on Clinical Trials in MS are funded by the European Committee for Treatment and Research in Multiple Sclerosis and the National Multiple Sclerosis Society.

\section{Disclosure}

F.D. Lublin discloses consulting arrangements with Biogen, EMD Serono, Novartis, Teva, Actelion, Sanofi/Genzyme, Acorda, Roche/Genentech, MedImmune/Viela Bio, Receptos/Celgene, TG Therapeutics, MedDay, Atara Biotherapeutics, Polpharma, Mapi Pharma, Innate Immunotherapeutics, Apitope, Orion Biotechnology, Brainstorm Cell Therapeutics, Jazz Pharmaceuticals, GW Pharma, Mylan, Immunic, and Population Council. T. Coetzee has nothing to disclose. J.A. Cohen reports personal compensation for consulting for Convelo, Mylan, and Population Council and serving as an Editor of Multiple Sclerosis Journal. R A. Marrie receives funding from the Canadian Institutes of Health Research, Research Manitoba, Multiple Sclerosis Society of Canada, Multiple Sclerosis Scientific Foundation, Crohn's and Colitis Canada, National Multiple Sclerosis Society, and the Consortium of Multiple Sclerosis Centers. She is supported by the Waugh Family Chair in Multiple Sclerosis. A.J. Thompson reports personal fees paid to his institution and other from Eisai Ltd and Hoffmann-La Roche; is an editorial board member for The Lancet Neurology receiving a free subscription; is Editor-inChief for Multiple Sclerosis Journal receiving an honorarium from SAGE Publications; receives support for travel as Chair, Scientific Advisory Committee, International Progressive MS Alliance, and from the National MS Society (USA) as member, NMSS Research Programs Advisory Committee; and received honoraria and support for travel for lecturing from EXCEMED and Almirall. Support is acknowledged from the UCL/UCLH NIHR Biomedical Research Centre. Go to Neurology.org/N for full disclosures.

\section{Publication history}

Received by Neurology January 22, 2020. Accepted in final form April 1, 2020.

\section{Appendix 1 Authors}

\begin{tabular}{lll}
\hline Name & Location & Contribution \\
\hline $\begin{array}{ll}\text { Fred D. } \\
\text { Lublin, MD }\end{array}$ & Icahn School of Medicine at & $\begin{array}{l}\text { Drafting of the } \\
\text { manuscript, revision of } \\
\end{array}$ \\
& $\begin{array}{l}\text { the manuscript, } \\
\text { and approval of the } \\
\text { final version for } \\
\text { publication }\end{array}$ \\
& \\
&
\end{tabular}


Appendix 1 (continued)

\begin{tabular}{|c|c|c|}
\hline Name & Location & Contribution \\
\hline $\begin{array}{l}\text { Timothy } \\
\text { Coetzee, } \\
\text { PhD }\end{array}$ & $\begin{array}{l}\text { National MS Society, New York, } \\
\text { United States }\end{array}$ & $\begin{array}{l}\text { Drafting of the } \\
\text { manuscript, revision of } \\
\text { the manuscript, } \\
\text { and approval of the } \\
\text { final version for } \\
\text { publication }\end{array}$ \\
\hline $\begin{array}{l}\text { Jeffrey A. } \\
\text { Cohen, MD }\end{array}$ & $\begin{array}{l}\text { Cleveland Clinic, Cleveland, } \\
\text { United States }\end{array}$ & $\begin{array}{l}\text { Revision of the } \\
\text { manuscript and } \\
\text { approval of the } \\
\text { final version for } \\
\text { publication }\end{array}$ \\
\hline $\begin{array}{l}\text { Ruth A. } \\
\text { Marrie, MD, } \\
\text { PhD }\end{array}$ & $\begin{array}{l}\text { University of Manitoba, } \\
\text { Winnipeg, Canada }\end{array}$ & $\begin{array}{l}\text { Revision of the } \\
\text { manuscript and } \\
\text { approval } \\
\text { of the final version for } \\
\text { publication }\end{array}$ \\
\hline $\begin{array}{l}\text { Alan J. } \\
\text { Thompson, } \\
\text { MD }\end{array}$ & $\begin{array}{l}\text { University College London, } \\
\text { London, United Kingdom }\end{array}$ & $\begin{array}{l}\text { Drafting of the } \\
\text { manuscript, revision of } \\
\text { the manuscript, } \\
\text { and approval of the } \\
\text { final version for } \\
\text { publication }\end{array}$ \\
\hline
\end{tabular}

\section{Appendix 2 Coinvestigators}

\begin{tabular}{|c|c|c|c|}
\hline Name & Location & Role & Contribution \\
\hline $\begin{array}{l}\text { Maria Pia } \\
\text { Amato }\end{array}$ & $\begin{array}{l}\text { University of } \\
\text { Florence Florence, } \\
\text { Italy }\end{array}$ & $\begin{array}{l}\text { Committee } \\
\text { member }\end{array}$ & $\begin{array}{l}\text { Reviewed the } \\
\text { manuscript }\end{array}$ \\
\hline $\begin{array}{l}\text { Frederik } \\
\text { Barkhof }\end{array}$ & $\begin{array}{l}\text { VU University } \\
\text { Amsterdam, } \\
\text { Amsterdam, } \\
\text { Netherlands }\end{array}$ & $\begin{array}{l}\text { Committee } \\
\text { member }\end{array}$ & $\begin{array}{l}\text { Reviewed the } \\
\text { manuscript }\end{array}$ \\
\hline $\begin{array}{l}\text { Tanuja } \\
\text { Chitnis }\end{array}$ & $\begin{array}{l}\text { Brigham and } \\
\text { Women's Hospital, } \\
\text { Boston }\end{array}$ & $\begin{array}{l}\text { Committee } \\
\text { member }\end{array}$ & $\begin{array}{l}\text { Reviewed the } \\
\text { manuscript }\end{array}$ \\
\hline $\begin{array}{l}\text { Giancarlo } \\
\text { Comi }\end{array}$ & $\begin{array}{l}\text { University Vita-Salute } \\
\text { San Raffaele, Milan, } \\
\text { Italy }\end{array}$ & $\begin{array}{l}\text { Committee } \\
\text { member }\end{array}$ & $\begin{array}{l}\text { Reviewed the } \\
\text { manuscript }\end{array}$ \\
\hline $\begin{array}{l}\text { Jorge } \\
\text { Correale }\end{array}$ & $\begin{array}{l}\text { Raúl Carrea Institute for } \\
\text { Neurologic Research } \\
\text { (FLENI) Buenos Aires, } \\
\text { Argentina }\end{array}$ & $\begin{array}{l}\text { Committee } \\
\text { member }\end{array}$ & $\begin{array}{l}\text { Reviewed the } \\
\text { manuscript }\end{array}$ \\
\hline Gary Cutter & $\begin{array}{l}\text { University of Alabama } \\
\text { at Birmingham, } \\
\text { Birmingham }\end{array}$ & $\begin{array}{l}\text { Committee } \\
\text { member }\end{array}$ & $\begin{array}{l}\text { Reviewed the } \\
\text { manuscript }\end{array}$ \\
\hline $\begin{array}{l}\text { Tobias } \\
\text { Derfuss }\end{array}$ & $\begin{array}{l}\text { University Basel, Basel, } \\
\text { Switzerland }\end{array}$ & $\begin{array}{l}\text { Committee } \\
\text { member }\end{array}$ & $\begin{array}{l}\text { Reviewed the } \\
\text { manuscript }\end{array}$ \\
\hline $\begin{array}{l}\text { Marcia } \\
\text { Finlayson }\end{array}$ & $\begin{array}{l}\text { Queens University, } \\
\text { London, Canada }\end{array}$ & $\begin{array}{l}\text { Committee } \\
\text { member }\end{array}$ & $\begin{array}{l}\text { Reviewed the } \\
\text { manuscript }\end{array}$ \\
\hline Ari Green & $\begin{array}{l}\text { University of California } \\
\text { San Francisco, San } \\
\text { Francisco }\end{array}$ & $\begin{array}{l}\text { Committee } \\
\text { member }\end{array}$ & $\begin{array}{l}\text { Reviewed the } \\
\text { manuscript }\end{array}$ \\
\hline
\end{tabular}

Appendix 2 (continued)

\begin{tabular}{|c|c|c|c|}
\hline Name & Location & Role & Contribution \\
\hline $\begin{array}{l}\text { Hans-Peter } \\
\text { Hartung }\end{array}$ & $\begin{array}{l}\text { Heinrich-Heine- } \\
\text { University, Düsseldorf, } \\
\text { Germany }\end{array}$ & $\begin{array}{l}\text { Committee } \\
\text { member }\end{array}$ & $\begin{array}{l}\text { Reviewed the } \\
\text { manuscript }\end{array}$ \\
\hline $\begin{array}{l}\text { Bernhard } \\
\text { Hemmer }\end{array}$ & $\begin{array}{l}\text { Technical University of } \\
\text { Munich, Munich, } \\
\text { Germany }\end{array}$ & $\begin{array}{l}\text { Committee } \\
\text { member }\end{array}$ & $\begin{array}{l}\text { Reviewed the } \\
\text { manuscript }\end{array}$ \\
\hline Aaron Miller & $\begin{array}{l}\text { Mount Sinai School of } \\
\text { Medicine, New York }\end{array}$ & $\begin{array}{l}\text { Committee } \\
\text { member }\end{array}$ & $\begin{array}{l}\text { Reviewed the } \\
\text { manuscript }\end{array}$ \\
\hline $\begin{array}{l}\text { Xavier } \\
\text { Montalban }\end{array}$ & $\begin{array}{l}\text { University of Toronto, } \\
\text { Toronto, Canada }\end{array}$ & $\begin{array}{l}\text { Committee } \\
\text { member }\end{array}$ & $\begin{array}{l}\text { Reviewed the } \\
\text { manuscript }\end{array}$ \\
\hline Ellen Mowry & $\begin{array}{l}\text { Johns Hopkins } \\
\text { University, Baltimore }\end{array}$ & $\begin{array}{l}\text { Committee } \\
\text { member }\end{array}$ & $\begin{array}{l}\text { Reviewed the } \\
\text { manuscript }\end{array}$ \\
\hline $\begin{array}{l}\text { Alex Rovira } \\
\text { Cañellas }\end{array}$ & $\begin{array}{l}\text { Universitat Autònoma } \\
\text { de Barcelona, } \\
\text { Barcelona Spain }\end{array}$ & $\begin{array}{l}\text { Committee } \\
\text { member }\end{array}$ & $\begin{array}{l}\text { Reviewed the } \\
\text { manuscript }\end{array}$ \\
\hline Amber Salter & $\begin{array}{l}\text { Washington University } \\
\text { St. Louis, St. Louis }\end{array}$ & $\begin{array}{l}\text { Committee } \\
\text { member }\end{array}$ & $\begin{array}{l}\text { Reviewed the } \\
\text { manuscript }\end{array}$ \\
\hline $\begin{array}{l}\text { Per Soelberg } \\
\text { Sørensen }\end{array}$ & $\begin{array}{l}\text { Copenhagen University } \\
\text { Hospital Rigshospitalet, } \\
\text { Copenhagen, Denmark }\end{array}$ & $\begin{array}{l}\text { Committee } \\
\text { member }\end{array}$ & $\begin{array}{l}\text { Reviewed the } \\
\text { manuscript }\end{array}$ \\
\hline $\begin{array}{l}\text { Maria Pia } \\
\text { Sormani }\end{array}$ & $\begin{array}{l}\text { University of Genoa, } \\
\text { Genoa, Italy }\end{array}$ & $\begin{array}{l}\text { Committee } \\
\text { member }\end{array}$ & $\begin{array}{l}\text { Reviewed the } \\
\text { manuscript }\end{array}$ \\
\hline Mar Tintore & $\begin{array}{l}\text { Universitat Autònoma } \\
\text { de Barcelona, } \\
\text { Barcelona, Spain }\end{array}$ & $\begin{array}{l}\text { Committee } \\
\text { member }\end{array}$ & $\begin{array}{l}\text { Reviewed the } \\
\text { manuscript }\end{array}$ \\
\hline $\begin{array}{l}\text { Maria } \\
\text { Trojano }\end{array}$ & $\begin{array}{l}\text { University of Bari, Bari, } \\
\text { Italy }\end{array}$ & $\begin{array}{l}\text { Committee } \\
\text { member }\end{array}$ & $\begin{array}{l}\text { Reviewed the } \\
\text { manuscript }\end{array}$ \\
\hline $\begin{array}{l}\text { Bernard } \\
\text { Uitdehaag }\end{array}$ & $\begin{array}{l}\text { VU University Medical } \\
\text { Center, Amsterdam, } \\
\text { Netherlands }\end{array}$ & $\begin{array}{l}\text { Committee } \\
\text { member }\end{array}$ & $\begin{array}{l}\text { Reviewed the } \\
\text { manuscript }\end{array}$ \\
\hline $\begin{array}{l}\text { Sandra } \\
\text { Vukusic }\end{array}$ & $\begin{array}{l}\text { Hôpital Neurologique } \\
\text { Pierre } \\
\text { Werthemier-GHE, } \\
\text { Lyon, France }\end{array}$ & $\begin{array}{l}\text { Committee } \\
\text { member }\end{array}$ & $\begin{array}{l}\text { Reviewed the } \\
\text { manuscript }\end{array}$ \\
\hline $\begin{array}{l}\text { Emmanuelle } \\
\text { Waubant }\end{array}$ & $\begin{array}{l}\text { University of California } \\
\text { San Francisco, San } \\
\text { Francisco }\end{array}$ & $\begin{array}{l}\text { Committee } \\
\text { member }\end{array}$ & $\begin{array}{l}\text { Reviewed the } \\
\text { manuscript }\end{array}$ \\
\hline $\begin{array}{l}\text { Dean } \\
\text { Wingerchuk }\end{array}$ & Mayo Clinic, Scottsdale & $\begin{array}{l}\text { Committee } \\
\text { member }\end{array}$ & $\begin{array}{l}\text { Reviewed the } \\
\text { manuscript }\end{array}$ \\
\hline
\end{tabular}

\section{References}

1. Lublin FD, Reingold SC. Defining the clinical course of multiple sclerosis: results of an international survey. National multiple sclerosis society (USA) advisory committee on clinical trials of new agents in multiple sclerosis. Neurology 1996; 46:907-911.

2. Lublin FD, Reingold SC, Cohen JA, et al. Defining the clinical course of multiple sclerosis: the 2013 revisions. Neurology 2014;83:278-286.

3. Food and Drug Administration (USA). Ocrelizumab Summary Review; 2017. Available at: accessdata.fda.gov/drugsatfda_docs/nda/2017/761053Orig1s000SumR.pdf. Accessed November 23, 2019.

4. European Medicines Agency. Summary of Opinion-Ocrevus; 2017. Available at: ema.europa.eu/en/documents/smop-initial/chmp-summary-positive-opinion-ocrevus en.pdf. Accessed September 23, 2019.

5. European Medicines Agency. Summary of Opinion-Mayzent; 2019. Available at: ema.europa.eu/en/documents/smop-initial/chmp-summary-positive-opinion-mayzent_en.pdf. Accessed September 23, 2019. 
6. Food and Drug Administration (USA). Siponimod Summary Review; 2019. Available at: accessdata.fda.gov/drugsatfda_docs/nda/2019/209884Orig1s000SumRpdf. Accessed September 23, 2019.

7. Food and Drug Administration (USA). Cladribine Summary Review; 2019. Available at: accessdata.fda.gov/drugsatfda_docs/nda/2019/022561Orig1s000SumR.pdf. Accessed September 23, 2019 .
8. Coetzee T, Thompson AJ. Unified understanding of MS course is required for drug development. Nat Rev Neurol 2018;14:191-192.

9. Thompson AJ, Banwell BL, Barkhof F, et al. Diagnosis of multiple sclerosis: 2017 revisions of the McDonald criteria. Lancet Neurol 2018;17:162173.

\section{COVID-19 and Neurologic Disease: Call for Papers!}

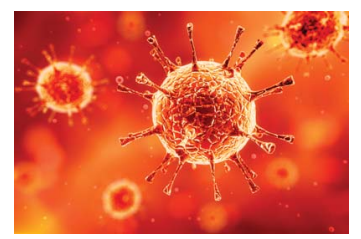

The editors of Neurology are interested in papers that address the neurological aspects of COVID-19 infection and challenges to the management of patients with chronic neurological conditions who have, or are at risk for, the infection. Relevant papers that pass initial internal review will undergo expedited peer review and online publication. We will consider papers posted in preprint servers.

Submit observational studies and clinical trials as Articles and case series and case reports under the Clinical/Scientific Notes category to https://submit.neurology.org/ today!

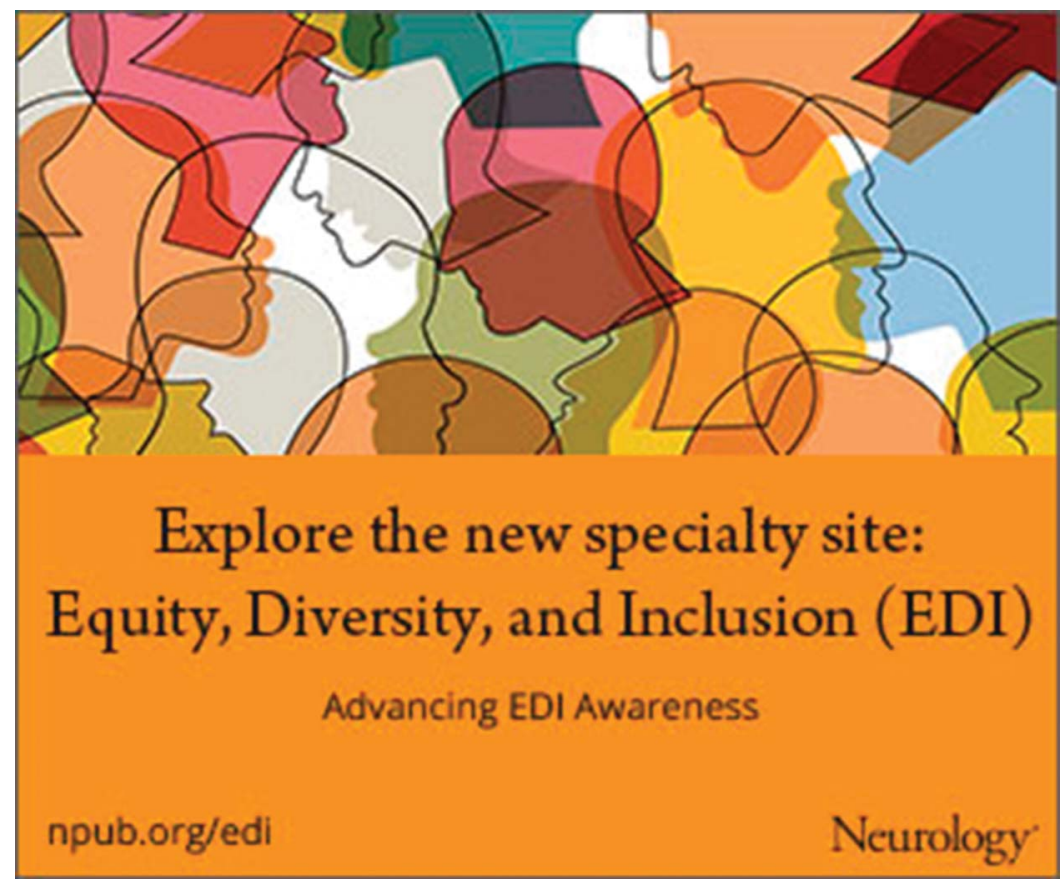




\section{Neurology}

The 2013 clinical course descriptors for multiple sclerosis: A clarification
Fred D. Lublin, Timothy Coetzee, Jeffrey A. Cohen, et al.

Neurology 2020;94;1088-1092 Published Online before print May 29, 2020

DOI 10.1212/WNL.0000000000009636

This information is current as of May 29, 2020

\section{Updated Information \& Services}

References

Citations

Subspecialty Collections

Errata

Permissions \& Licensing

Reprints including high resolution figures, can be found at: http://n.neurology.org/content/94/24/1088.full

This article cites 4 articles, 1 of which you can access for free at: http://n.neurology.org/content/94/24/1088.full\#ref-list-1

This article has been cited by 1 HighWire-hosted articles: http://n.neurology.org/content/94/24/1088.full\#\#otherarticles

This article, along with others on similar topics, appears in the following collection(s):

Multiple sclerosis

http://n.neurology.org/cgi/collection/multiple_sclerosis

An erratum has been published regarding this article. Please see next page or:

/content/98/5/215.3.full.pdf

Information about reproducing this article in parts (figures,tables) or in its entirety can be found online at:

http://www.neurology.org/about/about_the_journal\#permissions

Information about ordering reprints can be found online:

http://n.neurology.org/subscribers/advertise

Neurology ${ }^{\circledR}$ is the official journal of the American Academy of Neurology. Published continuously since 1951, it is now a weekly with 48 issues per year. Copyright Copyright ( 2020 The Author(s). Published by Wolters Kluwer Health, Inc. on behalf of the American Academy of Neurology.. All rights reserved. Print ISSN: 0028-3878. Online ISSN: 1526-632X.

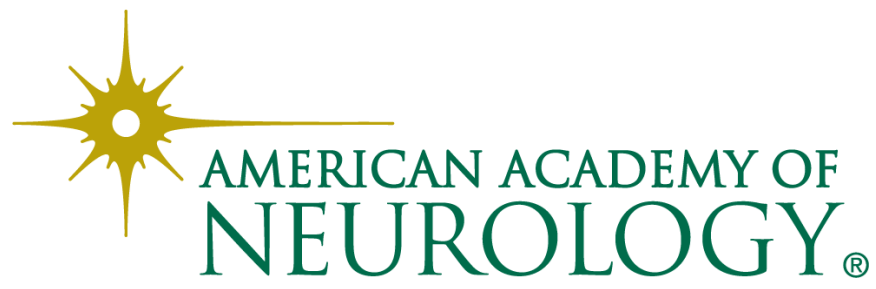




\section{Disputes \& Debates: Editors' Choice}

Steven Galetta, MD, FAAN, Editor

Aravind Ganesh, MD, DPhil, FRCPC, Deputy Editor

Ariane Lewis, MD, Deputy Editor

James E. Siegler III, MD, Deputy Editor

\section{Editors' Note: Randomized Study of Bedside vs Hallway Rounding: Neurology Rounding Study}

Dr. Solomon and colleagues reported their findings of a single-center prospective, randomized time-motion study of bedside vs hallway rounding. The investigators found no difference in rounding efficiency, although bedside rounds led to significantly greater time spent by providers with their patients. Nurses and patients responded more favorably to the bedside strategy, whereas residents felt that hallway rounds were more educational and permitted more accurate review of medical data (using an electronic medical record). Each rounding technique has its own advantages and disadvantages. As Dr. Sethi recounts from his training experience, bedside rounds may fuel trainee anxiety as they are simultaneously questioned by senior team members and scrutinized by patients during oral presentations. In conclusion, as with all medical management strategies, the optimal rounding paradigm is likely the one that is tailored to each unique clinical scenario.

James E. Siegler, MD, and Steven Galetta, MD

Neurology ${ }^{\circledR}$ 2022;98:214. doi:10.1212/WNL.0000000000013178

\section{Reader Response: Randomized Study of Bedside vs Hallway Rounding: Neurology Rounding Study}

Nitin K. Sethi (New York)

Neurology ${ }^{\circledR} 2022 ; 98: 214$. doi:10.1212/WNL.0000000000013179

I read with interest the study by Solomon et al. ${ }^{1}$ comparing bedside and hallway rounding. I did my medical school and residency training in Internal Medicine in India where rounds were conducted bedside twice daily. A detailed round occurred in the morning with the attending and the entire team. The patient was presented and examined, investigations were reviewed, and the care plan was discussed. The abridged round late in the afternoon with the senior resident followed up the events of the day and acted as a sign-out to the night call team. As residents, we dreaded the morning rounds because we were quizzed on our knowledge of the patients' presentation and management, but it also helped us to become good bedside clinicians and master the skills of clinical examination. In fact, Charles Miller Fisher, an expert neurologist, proposed that "the method of clinical observation should be just as rigorous as that of the laboratory bench." ${ }^{2}$

1. Solomon JM, Bhattacharyya S, Ali AS, et al. Randomized study of bedside vs hallway rounding: neurology rounding study. Neurology. 2021;97(9):434-442.

2. Caplan LR. Fisher's rules. Arch Neurol. 1982;39(7):389-390.

Copyright @ 2022 American Academy of Neurology 


\section{Author Response: Randomized Study of Bedside vs Hallway Rounding: Neurology Rounding Study}

Jacqueline M. Solomon (Hamilton, Ontario)

Neurology ${ }^{\circledR}$ 2022;98:215. doi:10.1212/WNL.0000000000013180

I am grateful to the reader for the thoughtful comment on our research and for sharing their own experience rounding at the bedside. ${ }^{1}$ I agree that even within the realm of bedside rounding, there are variations in how it is conducted. There are advantages and disadvantages to each rounding style and often there is room for the bedside rounding method to be improved, to provide trainees with the tools to become master clinicians without the intimidation factor of rounds that they so commonly dread.

1. Solomon JM, Bhattacharyya S, Ali AS, et al. Randomized study of bedside vs hallway rounding: neurology rounding study. Neurology. 2021;97(9):434-442.

Copyright @ 2022 American Academy of Neurology

\section{CORRECTIONS}

\section{A Clinico-Neurophysiological Study of Urogenital Dysfunction in MOG-Antibody Transverse Myelitis}

Neurology ${ }^{\circledR}$ 2022;98:215. doi:10.1212/WNL.0000000000012887

In the article "A Clinico-Neurophysiological Study of Urogenital Dysfunction in MOG-Antibody Transverse Myelitis" by Li et al., the x-axis of Figure 2 should have the label "no conus lesion" on the left and the label "conus lesion" on the right. The authors regret the error.

\section{Reference}

1. Li V, Malladi P, Simeoni S, et al. A clinico-neurophysiological study of urogenital dysfunction in MOG-antibody transverse myelitis. Neurology. 2020;95(21):e2924-e2934.

\section{The 2013 Clinical Course Descriptors for Multiple Sclerosis}

A Clarification

Neurology ${ }^{\circledR}$ 2022;98:215. doi:10.1212/WNL.0000000000011198

In the Views \& Reviews article "The 2013 Clinical Course Descriptors for Multiple Sclerosis: A Clarification” by Lublin et al., ${ }^{1}$ the contributions of Dr. Myla Goldman, Virginia Commonwealth University, were previously omitted from the author contributions section. Dr. Goldman was a committee member, and she reviewed the manuscript. The authors regret the error.

\section{Reference}

1. Lublin F, Coetzee T, Cohen J, et al. The 2013 clinical course descriptors for multiple sclerosis: a clarification. Neurology. 2020;94(24): 1088-1092. 